COMMENTARY

\title{
COVID-19 AND THE BIDOON IN KUWAIT: PANDEMIC OR STATELESSNESS VULNERABILITIES?
}

\author{
AREEJ AlshAMMIRY* \\ TABLE OF CONTENTS
}

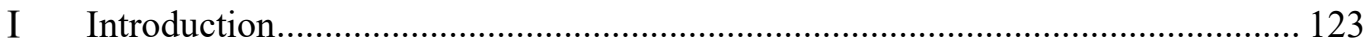

II How Pre-Pandemic Conditions Have Been Magnified During COVID-19 ......... 124

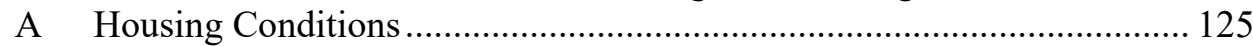

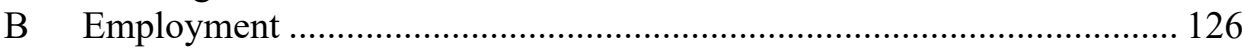

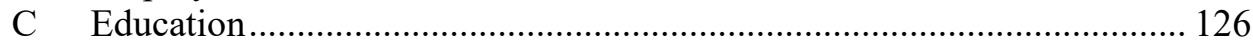

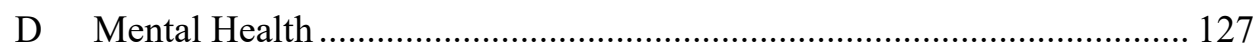

III Recent Debates on the Status of the Bidoon ....................................................... 128

\section{INTRODUCTION}

This piece outlines some of the conditions that the Bidoon (Kuwait's stateless population) have experienced during the COVID-19 pandemic. ${ }^{1}$ As a former stateless Bidoon and a researcher settled in Canada, I have utilised my community connections in Kuwait to inform my writing. The information in this article is gathered from speaking with at least eight Bidoon activists and stateless persons. I chose to keep their names anonymous for their safety. This work would not be possible without their contributions.

The exact number of the Bidoon is unavailable due to the contested nature of the statistics provided by the government. However, differing sources agree that this population is currently over 100,000 in Kuwait, excluding those who have migrated or have lived in exile since the 1990s. ${ }^{2}$ The Bidoon are indigenous to the Arabian Peninsula but were made stateless after the formation of the Kuwaiti state in the 1960s. The in situ stateless are prohibited from accessing many social services (including public education, proper healthcare, employment, documentation, subsidies and pension plans) and other basic human needs offered to citizens. ${ }^{3}$ The consequences of such deprivations are more severe for stateless people during a global crisis like the COVID-19 pandemic.

Areej Alshammiry is a research assistant in the office of the Vice President for the Intersections of Gender Signature Area. She is also doctoral student specialising in social justice and international studies. She researches, writes, advocates and consults about statelessness. Her research interests include statelessness, gender, race, class, nationalism and state violence. Through these concepts, she explores the ideological, cultural and material constructions of society in the Gulf region and Canada in her work.

1 Bidoon is short for bidoon jinsiya, which translates to 'without citizenship'. It is locally used as a category to define the stateless population in Kuwait. It is also used as an ethnic/class identity given its decades of politicised use by the government.

2 Claire Beaugrand. Stateless in the Gulf: Migration, Nationality and Society in Kuwait (I B Tauris 2018) 43.

3 In situ describes the kind of statelessness that is experienced by a person in their own country. 
After state formation, the Kuwaiti government naturalised many people that lived within its borders but left out the Bidoon. ${ }^{4}$ In 1986, the Government implemented policies that rendered the Bidoon unlawful residents after a secret decree, stripping them of access to significant rights and benefits including state welfare, education and employment. ${ }^{5}$ The restrictions banned the Bidoon from participating in many economic and social activities and resulted in mass layoffs of Bidoon employees from government and private jobs, creating severe impoverishment for many families. ${ }^{6}$

It is clear that, since 1986, the Bidoon have lived in difficult conditions. These conditions were aggravated when the COVID-19 pandemic hit. The situation of the Bidoon highlights how stateless people are among the most vulnerable populations during any global crisis.

\section{How Pre-PAndemic Conditions Have Been Magnified During}

COVID-19

After the liberation of Kuwait from the Iraqi invasion in 1991, a series of committees and administrative bodies were founded, including the Central Committee for the Affairs of Illegal Migrants in 1993, the Executive Committee for the Affairs of Illegal Migrants in 1996 and the Central System to Resolve the Situation of Illegal Residents in 2010 ('Central Apparatus'). ${ }^{7}$ These administrative bodies were 'presumably' created to solve the 'Bidoon problem'. However, from the perspective of the Bidoon, this created more problems than solutions. The Bidoon were banned from accessing public education, assigned false foreign identities and heavily policed.

Officials in the Central Apparatus coerced the Bidoon into denouncing their rights to nationality by requiring them to sign agreements acknowledging foreign nationalities in order to access basic services. ${ }^{8}$ These oppressive actions include psychological pressure tactics inflicted on the Bidoon in their day-to-day life. As the former Assistant Undersecretary for Nationality and Passports Affairs in the Ministry of Interior, Mazen Al-Jarrah, admitted in a television interview, 'I must pressure them psychologically and socially to get them to reveal their true nationalities'. 9 This pressure includes making access to any benefits nearly impossible without the approval of the Central Apparatus. The Bidoon cannot do

$4 \quad$ Beaugrand (n 2) 22.

5 Susan Kennedy, 'The Stateless Bedoun in Kuwait Society: A Study of Bedouin Identity, Culture and the Growth of an Intellectual Ideal' (PhD Thesis, The University of Adelaide 2016) $30-31$

$<$ https://digital.library.adelaide.edu.au/dspace/bitstream/2440/119698/2/02whole.pdf>; Beaugrand (n 2) 107.

6 Aziz Abu-Hamad, The Bedoons of Kuwait: Citizens without Citizenship (Report, Human Rights Watch August 1995) <https://www.hrw.org/reports/1995/Kuwait.htm> ('The Bedoons of Kuwait').

7 Claire Beaugrand, 'Framing Nationality in the Migratory Context: The Elusive Category of Biduns in Kuwait' (2014) 6(3) Middle East Law and Governance, 186 n 37.

8 Amnesty International, 'Kuwait: Mandate of Abusive Government Body in Charge of Stateless Bidun People Extended' (Media Release, 24 November 2020) $<$ https://www.amnesty.org/en/latest/news/2020/11/kuwait-mandate-of-abusive-governmentbody-in-charge-of-stateless-bidun-people-extended/> ('Kuwait Mandate').

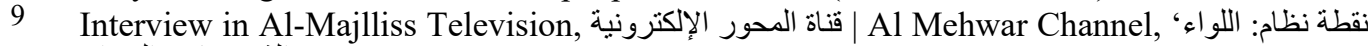
(YouTube, 29 November 2015) >https://youtu.be/Ds1As5si29s>. 
many things without a valid security card issued by the Central Apparatus and to receive one and access state services, the Bidoon must agree that they have false identities. ${ }^{10}$

Many families have refused to renew their security cards as a form of resistance to erasure and criminalisation, jeopardising their right to nationality. ${ }^{11}$ However, the consequences to this resistance have resulted in a lack of access to many benefits. Even with a valid security card, there are still many impediments to access. Many policies and practices in governmental institutions restrict services to the Bidoon. For example, valid security cards are not issued for long periods of time; they are often renewed for periods ranging from three months to one year. ${ }^{12}$ This precarity in legal status makes their access to basic services challenging. For instance, many employers prefer employees with long-term lawful status to avoid interruptions and legal problems arising from temporary status. ${ }^{13}$ As a result, many employers refuse to hire Bidoon employees. ${ }^{14}$ This temporary status entails a constant struggle for renewals in order to access necessary services. This example reflects the day-to-day lived experiences of the Bidoon, causing serious psychological damage because they are under the constant stress of losing their ability to sustain a livelihood. One of the devastating impacts of these practices against the Bidoon has been an increase in Bidoon suicides over the last few years, making it an urgent epidemic that must be addressed. ${ }^{15}$

\section{A Housing Conditions}

The majority of the Bidoon occupy 'popular' houses in two impoverished and underdeveloped cities: Taima and Sulaibiyah. ${ }^{16}$ Both cities are located on the outskirts of the Kuwait capital region and city centre where the main suburban areas are located. ${ }^{17}$ They have poor infrastructure and broken roads. These houses were constructed cheaply, with grey concrete bricks and without any finishing or painting. ${ }^{18}$ Generations of Bidoon families reside in these homes, with siblings and/or small units within large kin-based family, all cramped in one-, two- or three-bedroom houses. When the pandemic hit, transmission between family members was common given that many of them share rooms and have limited space to isolate or distance from each other. ${ }^{19}$ Furthermore, like many people during the pandemic, many employed Bidoon families lost their source of income

10 'Kuwait: Bidoon', World Directory of Minorities and Indigenous Peoples $<$ https://minorityrights.org/minorities/bidoon/> ('Kuwait: Bidoon'); 'Kuwait Mandate' (n 8).

11 Conversation with Bidoon activists (Areej Alshammiry, online, April 2021).

12 ibid.

13 See Prisoners of the Past: Kuwaiti Bidun and the Burden of Statelessness (Report, Human Rights Watch 13 June 2011) <https://www.hrw.org/report/2011/06/13/prisonerspast/kuwaiti-bidun-and-burden-statelessness> ('Prisoners of the Past').

14 Conversation with Bidoon activists (n 11).

15 Kuwait: Rising Signs of Despair Amongst Bidun Highlight Cruelty of Draft Law (Public Statement, MDE 17/1362/2019, Amnesty International, 21 November 2019) $<$ https://www.amnesty.org/en/documents/mde17/1362/2019/en/>.

16 Popular housing refers to a form of community housing plot made by the government to house people who make low-income for a temporary duration.

17 Kennedy (n 5) 171.

18 Farah Al-Nakib, 'Revisiting Hadar and Badū in Kuwait: Citizenship, Housing, and the Construction of a Dichotomy' (2014) 46(1) International Journal of Middle East Studies 5, 18-19.

19 Conversation with Bidoon activists (n 11). 
and were evicted or were at risk of being evicted for not paying rent on time. ${ }^{20}$ This persistent lack of employment put many families in vulnerable positions in the middle of a health crisis. Some families are living in tents in the desert because they cannot afford to rent a house. ${ }^{21}$

\section{B Employment}

Given their precarious status, many Bidoon do not have access to jobs and can only work if they have valid security cards. Some private companies hire Bidoon employees regardless of their status, taking advantage of their vulnerability and desperate need for income. ${ }^{22}$ However, these companies pay lower salaries, force Bidoon employees to wait months to get paid and require long working hours. ${ }^{23}$ Many are not eligible for vacation days or sick leave. Bidoon women are made especially vulnerable. For example, they are unable to take maternity leave; ${ }^{24}$ have fewer job options than their male counterparts; ${ }^{25}$ and, when faced with sexual harassment at work, they are likely to stay silent in order to keep their jobs. ${ }^{26}$ Employers are aware that the Bidoon are unprotected and the Bidoon rarely challenge the abusive conditions so they do not risk losing their jobs, especially if they are the sole income provider for their families. ${ }^{27}$

This precariousness and lack of protection for the Bidoon meant that they were among the first to be laid off when the pandemic hit. For those working in informal settings for day-to-day income, like selling merchandise and produce in public spaces or trading in cars, the curfew and lockdown made it difficult for them to continue this work and make money.

Finally, even when paid promptly, some Bidoons may not necessarily have access to the funds if they are paid into bank accounts. The Central Apparatus requires banks to block the Bidoon from accessing their accounts if their security cards are expired. ${ }^{28}$

\section{Education}

The Kuwaiti Government banned the Bidoon from accessing public education after criminalising their status. ${ }^{29}$ Consequently, illiteracy rates have grown because many families have been unable to afford to send their children to private schools. ${ }^{30}$ For those who were able to afford it, they sent their children to low-fee

20 ibid.

21 ibid.

22 Prisoners of the Past (n 13).

23 ibid.

24 Conversation with Bidoon activists (n 11); See Manshoor, 'The Forgotten Feminism: What Bidoon Women Face', Manshoor (Article, 3 July 2020) $<$ https://manshoor.com/society/bedon-women-forgotten-from-feminism/>.

25 ibid.

26 ibid; Kuwait: Bidoon (n 10); Conversation with Bidoon activists (n 11).

27 Conversation with Bidoon activists (n 11); 'The Forgotten Feminism' (n 24).

28 'The Closure of Bank Accounts for the Bidoon: Anger in Kuwait and the Ghanem Hints at Radical Solution' Teller Report (online, 18 April 2019) < https://www.tellerreport.com/news/-the-closure-of-bank-accounts-for-the-bidoon----anger-in-kuwait-and-the-ghanem-hints-ata-radical-solution-.Hy-rzxIq4.html>.

29 The Bedoons of Kuwait (n 6).

30 ibid. 
private schools in turns every year, leaving some at home for periods ranging from one to three years. ${ }^{31}$ Some families frequently prioritised boys' education over girls, leaving many girls without education and creating severe gender inequality. As a result, many Bidoon have either had to quit primary or secondary education, or have had consistent interruptions in their schooling. If they were able to complete their education, it was often in schools that offered lower quality education in relation to the education offered in other private institutions. ${ }^{32}$ Many have not been able to pursue post-secondary education as government institutions only enrol a small number of Bidoon students who have outstanding grades, often in very limited program choices. ${ }^{33}$

The main challenge the Bidoon face with regard to education is funding. Many families depend on donations to send their children to school. ${ }^{34}$ Schools also take an extra fee portion for each Bidoon student depending on their year level (primary, intermediate and secondary) above the tuition fees covered by the charity fund. Students are not allowed to access their classrooms if they have not paid their tuition in full. ${ }^{35}$ Sometimes they force students to stand out in the school yard in severe weather conditions until their parents arrive to either pay the outstanding amounts or take them home. ${ }^{36}$ During the pandemic, students whose fees were outstanding were barred from accessing the Zoom sessions until they paid their fees. ${ }^{37}$

Another challenge that arose during the pandemic in relation to online schooling was that many students needed electronic devices and internet access, things many Bidoon families struggled to provide for their children. ${ }^{38}$ Given that schools required each child to have their own device to complete their homework, this was a large barrier. Activists led a campaign on Twitter called نساهمبتعليمه and gathered donations to help cover expenses for these technologies. 39

The other effect of online schooling is the necessary unpaid labour at home to assist children in their studies and homework, something which became a challenge generally for many families around the world as schooling shifted online. For many Bidoon families, this was a particular challenge given that many family members are either illiterate or otherwise unequipped to help their children at home. The latter may be because they also had to work to provide income for the house or have full-time domestic labour responsibilities, but is not limited to these reasons.

\section{Mental Health}

For the Bidoon, mental health illnesses are already a common occurrence, given the oppressions - including social stigma, economic impoverishment, exclusion

31 Prisoners of the Past (n 13); Conversation with Bidoon activists (n 11).

32 Prisoners of the Past (n 13).

33 ibid.

34 ibid; Conversation with Bidoon activists (n 11).

35 Conversation with Bidoon activists (n 11).

36 ibid.

37 ibid.

38 ibid

39 See, eg, @JosephBohamad (Joseph Bohamad) (Twitter, 8 September 2020, 4:01pm AEST) $<$ https://t.co/t3oHYj66aM>; @HadeeLBuQrais (Hadeel Buqrais) (Twitter, 21 September 2020, 12:18am AEST) <https://t.co/oNGjVI3eM2>. 
and erasure - that they have now faced for decades. Many Bidoons carry intergenerational traumas; COVID-19 has made these struggles worse. This is compounded by a lack of access to proper mental health care, which is a challenge for most people in Kuwait. ${ }^{40}$ In addition to cultural stigma and a lack of education on mental illnesses, there are difficulties in accessing proper care. The Kuwait public hospital for psychiatric and psychological care is not equipped to handle large numbers of patients. ${ }^{41}$ Many people seek care in private mental health clinics, which are expensive even for citizens with average incomes. ${ }^{42}$ This makes them inaccessible for many Bidoons who already struggle financially.

The Bidoon must manage an already grave mental health crisis, but this was exacerbated by COVID-19. During the pandemic, Bidoon suicides increased, reaching at least five within a period of 12 months, from one or two yearly. ${ }^{43} \mathrm{In}$ February 2021, a 12-year-old boy, Ali Khaled, died by suicide in his home in Sulaibiya. ${ }^{44}$ Within the series of suicides that have taken place, this case involved a child, which shocked many people. ${ }^{45}$ While the Bidoon community and public were mourning his tragic death and expressing their outrage at the state actions and inaction that led to a child's suicide, a 26-year-old Bidoon man, Yaqoub Abdullah, died by suicide a month after Ali Khaled's death. ${ }^{46}$ Suicide rates among the Bidoon have been deeply troubling over the last two to three years, with others experiencing suicidal ideations and failed attempts. ${ }^{47}$ However, the Government has continued its previous policies, ignoring the severe impacts they have had on the Bidoon.

\section{Recent Debates on the Status of the Bidoon}

When the pandemic started, medical staff were key frontline workers in every country. In Kuwait, some of these workers are Bidoon, many of whom are employed by the Ministry of Health with no benefits and comparatively lower salaries than their colleagues. ${ }^{48}$ Bidoon medical workers are barred from joining residency programs to specialise, while there are also Bidoon medical graduates

40 Conversation with Bidoon activists (n 11).

41 Hind Almazeedi and Mohammad T Alsuwaidan, 'Integrating Kuwait's Mental Health System to End Stigma: A Call to Action' (2014) 23(1) Journal of Mental Health 1, 1-3.

42 Conversation with Bidoon activists (n 11).

43 This observation was made by the author in the course of her research.

44 Nadda Osman, 'Outcry in Kuwait over Suicide of Stateless Bidoon Child', Middle East Eye (online, 23 February 2021) <https://www.middleeasteye.net/news/suicide-stateless-bidoonchild-kuwait-prompts-outcry-online $>$.

45 ibid.

46 Khitam Al Amir, 'Kuwait: Young "Bidoon” Man Hangs Himself from a Tree', Gulf News (online, 28 March 2021) <https:/gulfnews.com/world/gulf/kuwait/kuwait-young-bidoonman-hangs-himself-from-a-tree-1.78170152>.

47 'Kuwait: Rising Signs of Despair Among Bidun Highlight Cruelty of Draft Law' (Public Statement, Amnesty $\quad$ International $21 \quad$ November 2019) $<$ https://www.amnesty.org/download/Documents/MDE1713622019ENGLISH.pdf>.

48 Conversation with Bidoon activists (n 11). This phenomenon has also been observed by the author in the course of her research. 
who remain at home with no employment. ${ }^{49}$ However, they were among the first to respond when the crisis began. 50 These actions were praised by the public and perceived as heroic acts in light of the oppressions they endure. ${ }^{51}$ It was hoped by many Bidoon that these actions would enable the state to see the value of the frontline workers and graduates and lead to naturalisation, ${ }^{52}$ as many states, including France and Canada, took similar actions in recognition of their frontline workers and international students. ${ }^{53}$ However, no prospect of citizenship has arisen: the volunteers were asked to stop showing up and the employees continue to work in the same pre-pandemic conditions. These employment conditions have discouraged Bidoon graduates from being optimistic about their career prospects in Kuwait. ${ }^{54}$ Many graduates and students live with the constant anxiety of never finding a job or working in a setting with terrible conditions. In July 2020, a Bidoon medical student died by suicide. ${ }^{55}$ As suicide rates increase, questions arise as to the severity of the conditions that the Bidoon live with in Kuwait.

The Government's stance on the Bidoon during a time of crisis reveals that they will continue to marginalise the Bidoon and have no interest in naturalising them. Just prior to COVID-19, the Speaker of the Kuwaiti Parliament, Marzouq AlGhanim, attempted to pass a new law that would further entrench the Bidoon as illegal residents and require they identify as their presumed foreign nationalities in order to have access to rights. ${ }^{56}$ The law was proposed in response to public critique about the failure of the administration, as it was presumed that they would solve the 'Bidoon problem' within five years of initiation but has instead only complicated the issue. However, the law only makes official what the Central Apparatus is already doing informally. Al-Ghanim claimed that the law would ensure the Bidoon receive 'humanitarian' treatment and have rights, without

49 Thomas McGee, 'The COVID-19 Crisis and New Agency for Stateless Bidoon in Kuwait', London School of Economics Blog (Blog Post, 27 April 2020) $<$ https://blogs.lse.ac.uk/mec/2020/04/27/the-covid-19-crisis-and-new-agency-for-statelessbidoon-in-kuwait/>; Conversation with Bidoon activists (n 11).

$50 \quad$ McGee (n 49).

51 ibid.

52 ibid.

53 See, eg, 'France Grants Citizenship to over 2,000 Foreign Workers for Covid-19 Response', France 24 (online, 5 May 2021) <https://www.france24.com/en/france/20210505-francegrants-citizenship-to-over-2-000-foreign-workers-for-covid-19-response $>$. 'New Pathway to Permanent Residency for over 90,000 Essential Temporary Workers and International Graduates', Immigration, Refugees and Citizenship Canada (online, 14 April 2021) $<$ https://www.canada.ca/en/immigration-refugees-citizenship/news/2021/04/new-pathwayto-permanent-residency-for-over-90000-essential-temporary-workers-and-internationalgraduates.html>.

54 Conversation with Bidoon activists (n 11).

55 The New Arab Staff, 'Stateless Kuwait Student's Suicide Attempt Leads to Outcry in Gulf State', The New Arab (online, 24 June 2020) <https://english.alaraby.co.uk/news/statelesskuwait-students-suicide-attempt-leads-outcry>.

56 Yasmena Al Mulla, 'Kuwait: MPs Do Not Show Up for Controversial Bidoon Law Session', Gulf News (online, 20 October 2020]) <https://gulfnews.com/world/gulf/kuwait/kuwait-mpsdo-not-show-up-for-controversial-bidoon-law-session-1.1603213775130>. 
interfering with Kuwaiti 'national identity'. 57 To counter it, the Bidoon worked in collaboration with the Kuwaiti Lawyers Association to draft an alternative law, in order to pressure Members of Parliament to adopt it instead. ${ }^{58}$ The 'lawyer's law', as it has been called, would entail the immediate naturalisation of a large number of the Bidoon under certain categories. This draft was not taken seriously. ${ }^{59}$ Neither law has passed, and the Bidoon remain perpetually stateless.

57 'Kuwait Promises "Fair Solution” for Stateless Bidoon Population, but Rejects Citizenship', The New Arab (online, 23 July 2019) $<$ https://english.alaraby.co.uk/english/news/2019/7/23/kuwait-promises-solutions-forbidoon-population-but-rejects-citizenship>; Al-Anbaa, 'Al-Ghanim: The Solution of the "Bidoon" is close' Al-Anbaa (online, 9 April 2019) <https://www.alanba.com.kw/ar/kuwaitnews/parliament/922133/05-09-2019-

\%D8\%A8\%D8\%A7\%D9\%84\%D9\%81\%D9\%8A\%D8\%AF\%D9\%8A\%D9\%88-

\%D8\%A7\%D9\%84\%D8\%BA\%D8\%A7\%D9\%86\%D9\%85-\%D8\%AD\%D9\%84$\% \mathrm{D} 8 \% \mathrm{~A} 7 \% \mathrm{D} 9 \% 84 \% \mathrm{D} 8 \% \mathrm{~A} 8 \% \mathrm{D} 8 \% \mathrm{AF} \% \mathrm{D} 9 \% 88 \% \mathrm{D} \% \% 86-$ $\% \mathrm{D} 8 \% \mathrm{~A} 7 \% \mathrm{D} \% \% 82 \% \mathrm{D} 8 \% \mathrm{AA} \% \mathrm{D} 8 \% \mathrm{~B} 1 \% \mathrm{D} 8 \% \mathrm{~A} 8 / ?>$.

58 'Lawyers Propose a Law to End the Conditions of the Bidoon', Al-Jarida Newspaper (online, 30 October 2019) <https:/www.aljarida.com/articles/1572449410382985800/>.

59 ibid. 